\title{
Effect on Histology and Nutrient Digestibility of Supplemented Origanum onites Essential Oil to Rainbow Trout Diets (Oncorhynchus mykiss)
}

\author{
Nalan Ozgur Yigit”, Oznur Diler, Seval Bahadir Koca, Oznur Gormez
}

Fisheries Faculty, Suleyman Demirel University, Isparta, TURKEY

\begin{abstract}
The present experiment was conducted to describe the effects on histology (experiment 1) and nutrient digestibility (experiment 2) of rainbow trout fed with diet containing $O$. onites oil. Diets were prepared with supplemented in different concentrate $(0,0.125$, $1.5,2.5,3.0 \mathrm{ml} \mathrm{kg}^{-1}$ ) of 0 . onites oil. A total of 1050 trout (body weight $26.05 \pm$ $0.15 \mathrm{~g})$ were randomly stocked into 15 tanks. The experiments were done in triplicate. In the experiment 1, rainbow trout were fed during 90 day for histology analysis. Five fish samples from per tank were taken at the end of the experiment. Liver and kidney histopathology of the control fish showed a normal histological architect without indication of any deformity. Slightly necrosis or degeneration were observed in liver and kidney samples of fish fed with high level of 0 . onites oil in diets. In the experiment 2, nutrient digestibility study was conducted for 2 week in following of the histology experiment. Nutrient digestibility was determined using $0.5 \% \mathrm{Cr}_{2} \mathrm{O}_{3}$ as an indicator to diet. Feces were collected by siphon from bottom of tanks during 2 week. The end of the experiment, dry matter, protein and lipid digestibility did not affect with supplemented in different concentrate of $O$. onites oil to trout diet.
\end{abstract}

Keywords: Origanum onites, Rainbow trout, Nutrient digestibility, Oregano, Histology.

\section{INTRODUCTION}

Essential oils are aromatic and volatile oily lipids obtained from plant material (flowers, buds, seeds, leaves, twigs, bark, wood, fruits and roots). These natural products have been reported to promote various functions like growth, ${ }^{1}$ immune responses ${ }^{2}$ and disease resistance ${ }^{3}$ in aquaculture due to essential oils contain many active components. Herbs and essential oils have been used traditionally for stimulate the production of endogenous secretions in the small intestinal mucosa, pancreas and liver, and thus aid digestion. ${ }^{4,5}$ Oregano (O. onites) is an aromatic plant with a wide distribution throughout the Mediterranean area. ${ }^{6,7}$ Oregano is a member of the Labiatae family of plants. Several researchers have tested the effect on growth of oregano oil on trout, ${ }^{8,9}$ channel catfish, ${ }^{10}$ sturgeon ${ }^{11}$ and tilapia. ${ }^{12}$ In the broiler researchers have shown that nutrient digestibility improved with addition of oregano essential oil, ${ }^{13}$ essential oil based on oregano ${ }^{14}$ and blends of essential oils extracted from oregano, cinnamon, and pepper ${ }^{15}$ to broilers diet. However, there have only been limited studies conducted to investigate the effects of essential oils on nutrient digestibility in fish. ${ }^{16}$ There is no study on influence of oregano oil on nutrient digestibility in rainbow trout diet. In addition, some researchers have described histological changes in tissues of fish fed diets containing different lipid sources. ${ }^{17,18}$ Histological analysis of the digestive system is considered a good indicator for understanding of the nutritional status of fish. ${ }^{19,20,21}$ The liver is the most important organ in digestion and absorption of nutrients from food,
DOI: 10.5530/ijper.51.3s.26 Correspondence: Nalan Ozgur Yigit,

Fisheries Faculty, Suleyman Demirel University, Isparta, TURKEY

Tel: 0902462118646 , Fax: 0902462118697 E-mail: nalanyigit@sdu. edu.tr 
and therefore monitoring of these organs is considered necessary. ${ }^{22,23}$ Histopathological changes may provide insight into the effects of unhealthy diets on various tissues and organs in fish. Histological changes in tissue of fish fed diets containing $O$. onites essential oil have not been investigated.

Therefore, the aim of the present study was to determine the effects on tissue histology and nutrient digestibility of $O$. onites essential oils supplemented in five different concentrate in rainbow trout (O. mykiss).

\section{MATERIAL AND METHODS}

\section{Diet preparation}

Experimental diets were formulated to fulfil the nutritional requirements of rainbow trout (New 1987). Five experimental diets were prepared with the supplementation of $O$. onites essential oil at the concentrations of 0, 0.125, 1.5, 2.5 and $3.0 \mathrm{ml} \mathrm{kg}^{-1}$ for diets Control, Diet 1, Diet 2, Diet 3 and Diet 4, respectively. Formulation of experimental diets and proximate analysis was shown in Table 1. The ingredients used in the experiment were obtained from the local market. All the ingredients were ground into fine powder. O. onites essential oils at predetermined levels were added to ingredients with together oil. All ingredients were mixed in a mixer, $20 \%$ distilled water were added, and pellets made with a laboratory pelletizer. The particle size of the diets was $5 \mathrm{~mm}$ and stored at $+4^{\circ} \mathrm{C}$ until used.

\section{Trout and experimental condition}

The experiments were carried out in 15 tanks. 1050 trout (mean weight of $26.05 \pm 0.15 \mathrm{~g}$ ) were stocked into 15 tanks. Histology and nutrient digestibility experiments were conducted for 90 day and 10 day, respectively. All fish were fed ad libitum. All experiments were done in triplicate. During the experimental period, water quality parameters such as dissolved oxygen level and temperatures were measured at $12^{\circ} \mathrm{C}$ and $7.5 \mathrm{mg} \mathrm{L}^{-1}$, respectively.

\section{Histological Examination}

Changes on liver and kidney histology of rainbow trout were examined on the end of the experiment 1 . Five fish from each tank were euthanized by overdose of MS-222 (200 $\mathrm{mgL}^{-1}$ of water for $10 \mathrm{~min}$ ) for organs collection. Organs were removed carefully, fixed immediately in

\begin{tabular}{|c|c|c|c|c|c|}
\hline \multicolumn{6}{|c|}{ Groups } \\
\hline & Control & Diet 1 & Diet 2 & Diet 3 & Diet 4 \\
\hline Fish meal & 35.00 & 35.00 & 35.00 & 35.00 & 35.00 \\
\hline Soybean meal & 30.00 & 30.00 & 30.00 & 30.00 & 30.00 \\
\hline Wheat gluten & 5.00 & 5.00 & 5.00 & 5.00 & 5.00 \\
\hline Wheat by-product & 14.00 & 13.99 & 13.85 & 13.75 & 13.70 \\
\hline Fish oil & 8.00 & 8.00 & 8.00 & 8.00 & 8.00 \\
\hline C vitamin & 0.50 & 0.50 & 0.50 & 0.50 & 0.50 \\
\hline $\mathrm{Cr}_{2} \mathrm{O}_{3}$ & 0.50 & 0.50 & 0.50 & 0.50 & 0.50 \\
\hline Pellet binder & 3.00 & 3.00 & 3.00 & 3.00 & 3.00 \\
\hline Antioksidant & 0.50 & 0.50 & 0.50 & 0.50 & 0.50 \\
\hline Mineral $^{1}$ & 1.00 & 1.00 & 1.00 & 1.00 & 1.00 \\
\hline Vitamin $^{2}$ & 2.00 & 2.00 & 2.00 & 2.00 & 2.00 \\
\hline Other & 0.50 & 0.50 & 0.50 & 0.50 & 0.50 \\
\hline O. onites oil & 0.00 & 0.0125 & 0.15 & 0.25 & 0.30 \\
\hline \multicolumn{6}{|c|}{ Chemical composition } \\
\hline Crude protein & $40.80 \pm 0.30$ & $41.00 \pm 0.20$ & $41.05 \pm 0.45$ & $40.54 \pm 0.54$ & $41.05 \pm 0.45$ \\
\hline Crude lipid & $20.05 \pm 0.45$ & $20.15 \pm 0.35$ & $19.40 \pm 0.30$ & $20.20 \pm 0.40$ & $20.10 \pm 0.60$ \\
\hline Crude cellulose & $2.60 \pm 0.10$ & $2.40 \pm 0.20$ & $2.55 \pm 0.35$ & $2.35 \pm 0.35$ & $2.45 \pm 0.05$ \\
\hline Crude ash & $8.15 \pm 0.35$ & $7.75 \pm 0.65$ & $7.60 \pm 0.50$ & $7.35 \pm 0.15$ & $8.10 \pm 0.10$ \\
\hline Moisture & $10.65 \pm 0.55$ & $11.20 \pm 0.40$ & $10.80 \pm 0.60$ & $11.10 \pm 0.30$ & $10.95 \pm 0.25$ \\
\hline
\end{tabular}

${ }^{1}$ Vitamin premix.; per kg, 4,000,000 IU vitamin A, 480,000 IU vitamin $\mathrm{D}_{3}$, 40,000 mg vitamin $\mathrm{E}_{1} 2400 \mathrm{mg}$ vitamin $\mathrm{K}_{3}$, 4,000 mg vitamin $\mathrm{B} 1$, 6,000 mg vitamin B2, 40,000 mg niacin, 10,000 mg calcium D-pantothenate, 4,000 mg vitamin B6, $10 \mathrm{mg}$ vitamin B12, $100 \mathrm{mg}$ D-biotin, 1,200 mg folic acid, 40,000 mg vitamin $\mathrm{C}$ and $60,000 \mathrm{mg}$ inositol.

${ }^{2}$ Mineral premix.; per kg 23,750 mg Mn, 75,000 mg Zn, 5,000 mg Zn, 2,000 mg Co, 2,750 mg l, $100 \mathrm{mg} \mathrm{Se,} \mathrm{200,000} \mathrm{mg} \mathrm{Mg.}$ 
Table 2: Mean percent apparent dry matter, protein and lipid digestibility of rainbow trout fed diet containing $\boldsymbol{O}$. onites oil

\begin{tabular}{|c|c|c|c|}
\hline & Lipid digestibility & Protein digestibility & Dry matter digestibility \\
\hline Control & $94.88 \pm 0.34$ & $91.04 \pm 0.10$ & $76.61 \pm 0.30$ \\
\hline Diet 1 & $94.54 \pm 0.30$ & $90.67 \pm 0.02$ & $76.35 \pm 0.35$ \\
\hline Diet 2 & $94.60 \pm 0.22$ & $90.85 \pm 0.49$ & $75.20 \pm 1.36$ \\
\hline Diet 3 & $95.01 \pm 0.46$ & $90.38 \pm 0.47$ & $74.97 \pm 0.90$ \\
\hline Diet 4 & $95.00 \pm 0.28$ & $90.04 \pm 0.31$ & $76.25 \pm 0.37$ \\
\hline
\end{tabular}

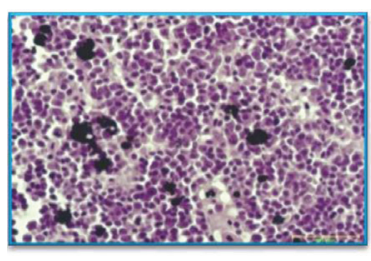

(a)

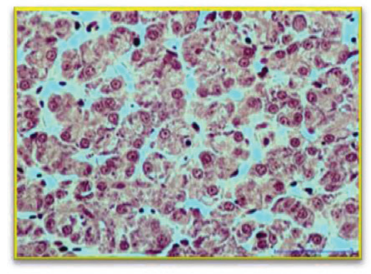

(c)

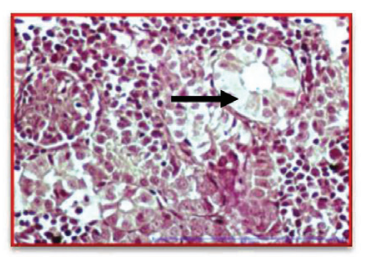

(b)

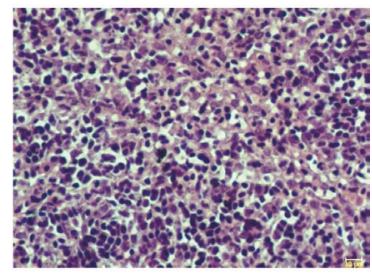

(d)

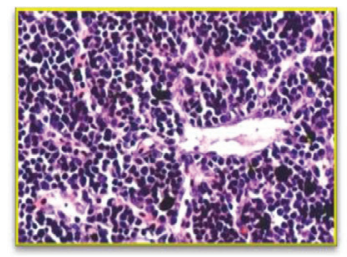

(a)

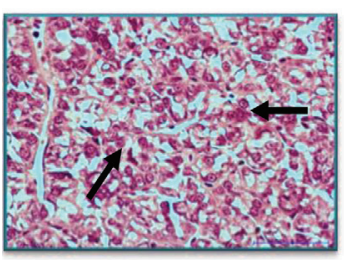

(c)

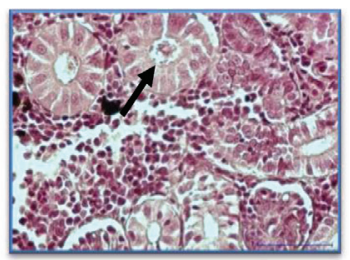

(b)

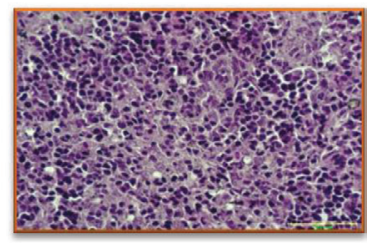

(d)
Figure 1: Kidney (a, b), liver (c) and spleen (d) histology of rainbow trout fed with $0.125 \mathrm{ml} \mathrm{kg}^{-1} \mathrm{O}$. onites. b; some necrotic changes in tubule epithelial cells (arrow) (H. and $\mathrm{E}$. stain $\times 40$ )

$10 \%$ buffered formalin, dehydrated in a graded ethanol series, and embedded in paraffin. Sections were cut at $5 \mu \mathrm{m}$, and stained with hematoxylin $(\mathrm{H})$ and eosin $(\mathrm{E})$ for light microscopic examination. ${ }^{24}$

\section{Digestibility study and analysis}

Chromic oxide $\left(\mathrm{Cr}_{2} \mathrm{O}_{3}\right)$ was added as an inert marker at $0.5 \%$ rate to diets for nutrient digestibility. ${ }^{25}$ Half an hour after feeding, tanks were siphoned to remove uneaten feed and fecal residues. Fecal matter was collected by siphon later three hour than feeding from each tank. Feces of each treatment were kept at $-20^{\circ} \mathrm{C}$ and then oven dried at $50^{\circ} \mathrm{C}$ for $48 \mathrm{~h}$ and analyzed. Apparent digestibility coefficients (ADC) of dry matter and nutrients were calculated using the formula as follows:

ADC of dry matter $=100-100 \times\left(\% \mathrm{Cr}_{2} 0_{3}\right.$ in diet $/ \%$ $\mathrm{Cr}_{2} \mathrm{O}_{3}$ in faeces)

$\mathrm{ADC}$ of nutrients $=100-100 \times\left(\% \mathrm{Cr}_{2} \mathrm{O}_{3}\right.$ in diet $/ \%$ $\mathrm{Cr}_{2} \mathrm{O}_{3}$ in faeces $) \times(\%$ nutrient in faeces $/ \%$ nutrient in diet)
Biochemical analyses of experimental samples were determined according to standard Association of Official Analytical Chemists methods. ${ }^{26}$ Moisture was analyzed by oven drying at $105^{\circ} \mathrm{C}$ for $24 \mathrm{~h}$. Crude protein was determined by the Kjeldahl method and multiplying by a factor of 6.25 . Crude ash was determined using a muffle furnace at $550^{\circ} \mathrm{C}$ for $24 \mathrm{~h}$. Crude fibre was determined by sample digestion with $\mathrm{H}_{2} \mathrm{SO}_{4}$ and $\mathrm{NaOH}$. Lipids were extracted from samples using the chloroform: methanol mixture. ${ }^{27}$

\section{Statistical Analysis}

Nutrient digestibility was analyzed by one way analysis of variance (ANOVA). All data were calculated by using SPSS computer program (SPSS 2000). The duncan test was used to determine the differences among treatment means $(\mathrm{P}=0.05)$.

\section{RESULTS}

Histological analysis of liver, kidney and spleen in control fish did not indicate any pathological changes. Liver 
and kidney of fish fed $O$. onites oil had slightly different histological characteristics from those of the control group. The main lesion in liver was hepatocyte cytoplasmic vacuolation. Although no changes was occurred in liver and spleen tissue (Figure 1c and Figure 1d), slightly necrotic changes in tubule epithelial cells in kidney (Figure 1b), cytoplasmic vacuolation in posterior kidney (Figure 2b) and necrosis in hepatocytes of liver (Figure 2c) were observed in rainbow trout fed with $0.125 \mathrm{ml} \mathrm{kg}^{-1}$ and $2.5 \mathrm{ml} \mathrm{kg}^{-1}$ O. onites in $\mathrm{H}$ and $\mathrm{E}$ stain, respectively. Other concentrations $\left(1.5\right.$ and $\left.3 \mathrm{ml} \mathrm{kg}^{-1}\right)$ were similar to $2.5 \mathrm{ml} \mathrm{kg}^{-1}$ O. onites.

Nutrient digestibility of trout fed with the different experimental diets is reported in Table 2. Dry matter, protein and lipid digestibility with addition of $O$. onites essential oil to trout diet no showed significant differences among groups $(p>0.05)$. Protein digestibility of rainbow trout fed adding $O$. onites ranged from 91.04 to $90.04 \%$, lipid digestibility was ranged from 94.54 to $95.01 \%$, dry matter digestibility ranged from 74.97 to $76.61 \%$ in all treatment.

\section{DISCUSSION}

In the present study, slightly necrosis or degeneration were observed in liver and kidney samples of fish fed with high level $\left(1.5,2.5\right.$ and $3 \mathrm{ml} \mathrm{kg}^{-1}$ O. onites $)$ of herbal oil containing diets. Negative effects of herbal oils on histological changes may be related to toxic constituents, excessive doses, or allergic conditions, but they generally have no effects on health when used in the proper doses and application. ${ }^{3-28}$ The results of the present study demonstrated that high level of herbal oil exerted slightly negative effects on organ histology of fish. Our findings were similar to the previous studies with $O$. mykiss. ${ }^{29}$ Also, Zakes et al. informed that negative effects on liver structure (increased necrosis and liver vacuolization) of fish fed extracts of two medicinal plants (Astragalus radix and Lonicera japonica) were observed. ${ }^{30}$

Digestibility of a feed is an important factor to consider in determining the utilization of the feed. In the present study, protein digestibility with addition of $\mathrm{O}$. onites essential oil in different ratio to trout diet showed no significant differences. There are a few studies conducted on the addition of essential oil in fish diet. Similarly, Villeda (2013) reported that addition of a commercial blend of oregano, anis and citrus essential oils to juvenile gilthead seabream diet had no effect on digestibility of protein ${ }^{16}$. Lin $e t$ al. informed that digestibility of protein decreased with increased of traditional chinese medicine comprising a mixture of six herbs to white shrimp diet. ${ }^{31}$ In contrast, Qiu et al. reported that protein digestibility increased in carp fed with mixture of six herbs. ${ }^{32}$ In broiler study, Cross et al. informed that addition of herb (thyme, oregano, marjoram, rosemary or yarrow) to broiler diet had no effect on dry matter digestibility. ${ }^{33}$ Suk et al. reported that protein digestibility is no effect with addition of blended essential oil to broiler diet. ${ }^{34}$ Lee $e t a l$. informed that digestibility of crude protein is not effect with addition of commercial preparation of essential oil components to broiler diet. ${ }^{35}$ In contrast, Basmacioğlu Malayoğlu et al. showed that addition of oregano essential oil to broilers diet improved protein digestibility ${ }^{13}$. Hernandez et al. reported that blends of essential oils extract from oregano, cinnamon and pepper have improved digestibility of dry matter and protein of broiler finisher diet. ${ }^{36}$

In the current study, lipid digestibility showed no effect with addition of $O$. onites oil to trout diet. Qiu et al. reported that digestibility of fat increased in carp fed with mixture of six herbs. ${ }^{37}$ Suk et al. reported that lipid digestibility no effect with addition of blended essential oil to broiler diet. ${ }^{34}$ Lee et al. informed that lipid digestibility not affect with addition of essential oil components to broiler diets. ${ }^{35}$

This study is first investigating on effect of oregano oil on histology and nutrient digestibility in rainbow trout diet. In the present study, slightly necrosis or degeneration were observed in tissue of fish fed with high level of oregano oil containing diets and nutrient digestibility with addition to trout diet of $O$. onites essential oil in different concentrate also did not effect.

\section{ACKNOWLEDGEMENTS}

This study was supported by the Scientific and Technical Research Council of TURKEY (project number 1120855).

\section{CONFLICT OF INTEREST}

None

\section{ABBREVIATION USED}

$\mathrm{H}$ : Hematoxylin; E: Eosin; $\mathrm{Cr}_{2} \mathrm{O}_{3}$ : Chromic oxide; ADC: Apparent digestibility coefficients.

\section{REFERANCES}

1. Shalaby AM, Khattab YA, Abdel Rahman AM. Effects of garlic (Allium sativum) and chloramphenicol on growth performance, physiological parameters and survival of Nile tilapia (Oreochromis niloticus). Journal of Venomous Animals and Toxins including Tropical Diseases. 2006;12(2):172-201.

2. Ergün S, Yılmaz S, Yigit M. Effects of thyme, rosemary and fenugreek on some hematological and immunological parameters of tilapia, Oreochromis 
mossambicus. Mediterranean Aquaculture 2020, Aquaculture Europe (EAS 2011), Rhodes-Greece. 2011;19-21.

3. Yılmaz S, Ergün S. Türk N. Effects of cumin-supplemented diets on growth and disease (Streptococcus iniae) resistance of tilapia (Oreochromis mossambicus). The Israeli Journal of Aquaculture - Bamidgeh. 2012;64:IJA_768.

4. Williams $P$, Losa R. The use of essential oils and their compounds in poultry nutrition. World Poult. 2001;17(4):14-5.

5. Lee KW. Essential oils in broiler nutrition. PhD Thesis. Uttercht University. 2002.

6. Kokkini S, Karousou R, Hanlidou E, Lanaras T. Essential oil composition of Greek (Origanum vulgare ssp hirtum) and Turkish (O. onites) oregano: a tool for their distinction. Journal of Essential Oil Research. 2004;16:334-8.

7. Temizkan I, Kamalak A, Canbolat O. Effect of oregano oil on in vitro gas production, digestibility and metabolisable energy of some feedstuffs. Journal of Applied Animal Research. 2011;39(2):132-5.

8. Ahmadifar E, Falahatkar B, Akrami R. Effects of dietary thymol-carvacrol on growth performance, hematological parameters and tissue composition of juvenile rainbow trout, Oncorhynchus mykiss. Journal of Applied Ichthyology. 2011;27(4):1057-60.

9. Diler O, Gormez O, Diler I, Metin S. Effect of oregano (Origanum onites L.) essential oil on growth, lysozyme and antioxidant activity and resistance against Lactococcus garvieae in rainbow trout, Oncorhynchus mykiss (Walbaum). Aquaculture Nutrition 2016.

10. Zheng ZL, Tan JY, Liu HY, Zhou XH, Xiang X, Wang KY. Evaluation of oregano essential oil (Origanum heracleoticum L.) on growth, antioxidant effect and resistance against Aeromonas hydrophila in channel catfish (Ictalurus punctatus). Aquaculture. 2009;292(3):214-8.

11. Ahmadifar E, Mansour MR, Amirkolaie AK, Rayeni MF. Growth efficiency, survival and haematological changes in great sturgeon (Huso huso Linnaeus, 1758) juveniles fed diets supplemented with different levels of thymol-carvacrol. Animal Feed Science and Technology. 2014;198:304-8.

12. Ahmad MH, El-Gamal RM, Hazaa MM, Hassan SM, El Araby DA. The use of Origanum vulgare extracts in practical diets as a growth and immunity promoter for Nile Tilapia, Oreochromis niloticus fingerlings challenged with pathogenic Pseudomonas aeruginosa and Pseudomonas flourescens. The Egyptıan Journal of Experimental Biology (Zoology) 2009;5:457-63.

13. Malayoğlu H, Baysal Ş, Misirlioğlu Z, Polat M, Yilmaz H, Turan N. Effects of oregano essential oil with or without feed enzymes on growth performance, digestive enzyme, nutrient digestibility, lipid metabolism and immune response of broilers fed on wheat-soybean meal diets. British poultry science. 2010;51(1):67-80.

14. Tabari DG, Rezvani MR, Zamiri MJ, Dadpasand M. The effect of oregano and thyme based essential oils and $\beta$-glucanase on performance and nutrients digestibility in broiler chicks fed barley-based diets. Journal of Veterinary Research. 2013;68(3):241-8

15. Hernandez F, Madrid J, Garcia, V, Orengo J, Megias MD. Influence of two plant extracts on broilers performance, digestibility, and digestive organ size. Poultry science, 2004;83(2):169-74.

16. Villeda C. Effect of dietary essential oils supplementation on growth performance, protein digestibility and digestive enzymes in juvenile gilthead seabream fed a low fishmeal diet (PhD Thesis). 2013.

17. Tucker JW, Llellis WA, Vermeer GK, Roberts DE, Woodward PN. The effects of experimental starter diets with different levels of soybean or menhaden oil on red drum (Sciaenops ocellatus). Aquaculture. 1997;149(3-4):323-39.

18. Bell JG, Dick JR, Mc Vicar AH, Sargent JR, Thompson KD. Dietary sunflower line seed and fish oils affected phospholipid fatty acid composition, development of cardiac lesions, phospholipase activity and eicosanoid production in Atlantic salmon, Salmo salar. Prostaglandins, Leukotrienes and Essential Fatty Acids. 1993;49(3):665-73.
19. Hall KC, Bellwood DR. Histological effects of cyanide, stress and starvation on the intestinal mucosa of Pomacentrus coelestis, a marine aquarium fish species. Journal of Fish Biology. 1995;47(3):438-54.

20. Green BS, McCornick MI. Influence of larval feeding history on the body condition of Amphiprion melanopus. Journal of Fish Biology. 1999;55(6):1273-89.

21. Caballero MJ, Izquierdo MS, Kjørsvik E, Montero D, Socorro J, Fernández AJ, et al. Morphological aspects of intestinal cells from gilthead seabream (Sparus aurata) fed diets containing different lipid sources. Aquaculture. 2003;225(1):325-40.

22. Takashima F, Hibiya T. An atlas of fish histology: normal and pathological features. Kodansha, distributed by Fischer, G. Tokyo. 1982.

23. Roberts RJ. Fish pathology. Baillière Tindall, London. 1989.

24. Bancroft JD, Stevens A, Theory and practice of histological techniques. Edinburgh, London and New York: Churchill Livingstone. 1977.

25. Spyridakis P, Metailler R. Gabaudan J, Riaza A. Studies on nutrient digestibility in European sea bass (Dicentrarchus labrax) 1. Methodological aspects concerning faeces collection. Aquaculture 1989; 77:61-70.

26. Association of Official Analytical Chemists (AOAC). Official methods of analysis. 16th ed. Arlington (VA), USA: Association of Official Analytical Chemists. 2000.

27. Bligh EG, Dyer WJ. Rapid method of total lipid extraction and purification. Canadian Journal of Biochemistry and Physiology. 1959;37(8):911-917.

28. Bandaranayake WM. Quality control, screening, toxicity, and regulation of herbal drugs. Modern Phytomedicine: Turning Medicinal Plants into Drugs 2006; 25-58.

29. Sönmez AD, Bilen S, Albayrak M, Yılmaz S, Biswas G, Hisar O, et al. Effects of dietary supplementation of herbal oils containing 1,8-cineole, carvacrol or pulegone on growth performance, survival, fatty acid composition, and liver and kidney histology of rainbow trout (Oncorhynchus mykiss) fingerlings. Turkish Journal of Fisheries and Aquatic Sciences. 2001;15:813-9.

30. Zakes Z, Kowalska A, Demska-Zakes K, Jeney G, Jeney Z. Effect of two medicinal herbs (Astragalus radix and Lonicera japonica) on growth performance and body composition of juvenile pikeperch (Sander lucioperca L.). Aquaculture Research. 2008;39(11):1149-60.

31. Lin HZ, Li ZJ, Chen YQ, Zheng WH, Yang K. Effect of dietary traditional Chinese medicines on apparent digestibility coefficients of nutrients for white shrimp Litopenaeus vannamei, Boone. Aquaculture. 2006;253(1):495-501.

32. Qiu X, Zhou H, Liu X, Hua X, Cao D, Zhang D. The effect of dietary Chinese herb additives on growth and digestibility of allogynogenetic crucian carp. Shuichan Xuebao. 2001;26(6):551-5.

33. Cross DE, McDevitt RM, Hillman K, Acamovic T. The effect of herbs and their associated essential oils on performance, dietary digestibility and gut microflora in chickens from 7 to 28 days of age. British Poultry Science. 2007;48(4):496-506.

34. Suk JC, Lim HS, Paik IK. Effects of blended essential oil (CRINA®) supplementation on the performance, nutrient digestibility, small intestinal microflora and fatty acid composition of meat in broiler chickens. Journal of Animal Science and Technology. 2003;45(5):777-86.

35. Lee KW, Everts H, Kappert HJ, Frehner M, Losa R, Beynen AC. Effects of dietary essential oil components on growth performance, digestive enzymes and lipid metabolism in female broiler chickens. British Poultry Science. 2003;44(3):450-7.

36. Hernandez F, Madrid J, Garcia V, Orengo J, Megias MD. Influence of two plant extracts on broilers performance, digestibility, and digestive organ size. Poultry Science. 2004;83(2):169-74.

37. Qiu XC, Zhou HQ, Hua XM, Liu XG, Cao D. The effect of dietary Chinese additives on digestibility of Allogynogenetic crucian carp. Journal of Xinyang Normal University (Natural Science Edition)(China). 2004;17(1):54-6. 


\section{PICTORIAL ABSTRACT}
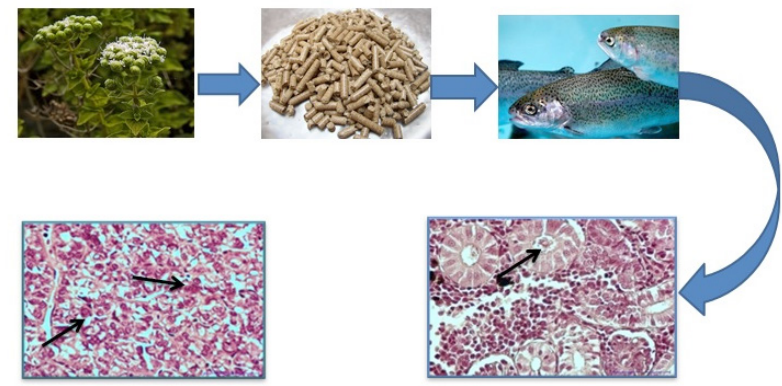

\section{SUMMARY}

- Slightly necrosis or degeneration were observed in liver and kidney samples of fish fed with high level of O. onites oil in diets.

- Dry matter, protein and lipid digestibility did not affect with supplemented in different concentrate of $O$. onites oil to trout diet.

\section{About Authors}

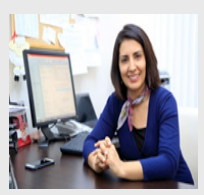

Nalan Ozgur YigiT is researcher at Fisheries Faculty, Suleyman Demirel University, Isparta, TURKEY. Research Interests Include Fish Nutrition and Aquaculture.

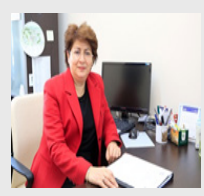

Oznur DiLER is researcher at Fisheries Faculty, Suleyman Demirel University, Isparta, TURKEY. Research Interests Include Fish Diseases, Fish Immunity and Aquaculture.

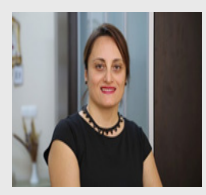

Seval BAHADIR KOCA is researcher at Fisheries Faculty, Suleyman Demirel University, Isparta, TURKEY. Research Interests Include Probiotic, Live Food, Cryfish and Aquaculture.

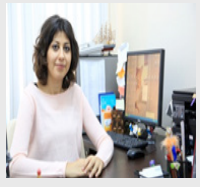

Oznur GORMEZ is researcher at Fisheries Faculty, Suleyman Demirel University, Isparta, TURKEY. Research Interests Include Fish Diseases and Aquaculture.

Cite this article: Yigit NO, Diler O, Koca SB, Gormez O. Effect on Histology and Nutrient Digestibility of Supplemented Origanum onites Essential Oil to Rainbow Trout Diets (Oncorhynchus mykiss). Indian J of Pharmaceutical Education and Research. 2017;51(3)Suppl:S262-67. 